TITLE:

\title{
Application of large-scale ring shear tests to the analysis of tsunamigenic landslides at the Stromboli volcano, Italy
}

\section{$\operatorname{AUTHOR(S):~}$}

Boldini, Daniela; Wang, Fawu; Sassa, Kyoji; Tommasi, Paolo

\section{CITATION:}

Boldini, Daniela ...[et al]. Application of large-scale ring shear tests to the analysis of tsunamigenic landslides at the Stromboli volcano, Italy. Landslides 2009, 6(3): 231-240

\section{ISSUE DATE:}

2009-09

URL:

http://hdl.handle.net/2433/86617

\section{RIGHT:}

c Springer-Verlag 2009.; この論文は出版社版でありません。引用の際 には出版社版をご確認ご利用ください。; This is not the published version. Please cite only the published version. 


\title{
Application of large scale ring shear tests to the analysis of
} tsunamigenic landslides at Stromboli

\author{
Daniela Boldini ${ }^{1}$, Fawu Wang ${ }^{2 *}$, Kyoji Sassa $^{3}$, Paolo Tommasi ${ }^{4}$ \\ ${ }^{1}$ Lecturer, Department of Chemical, Mining and Environmental Engineering, University of \\ Bologna, via Terracini 28, 40131 Bologna, Italy, e-mail: daniela.boldini@unibo.it \\ 2 Assistant Professor, Research Centre on Landslides, Disaster Prevention Research Institute, \\ Kyoto University, Gokasho, Uji, Kyoto 611-011, Japan; e-mail: \\ wangfw@landslide.dpri.kyoto-u.ac.jp \\ ${ }^{3}$ Emeritus Professor, Kyoto University, Japan; e-mail: sassa@,iclhq.org \\ ${ }^{4}$ Researcher, Institute for Geo-Engineering and Environmental Geology, National Research \\ Council, c/o Faculty of Engineering, via Eudossiana 18, 00184 Rome, Italy; e-mail: \\ paolo.tommasi@uniroma1.it \\ *Corresponding author: \\ Dr. Fawu Wang \\ Research Centre on Landslides, Disaster Prevention Research Institute, Kyoto University, \\ Gokasho, Uji, Kyoto 611-011, Japan; e-mail: wangfw@landslide.dpri.kyoto-u.ac.jp
}

Keywords: landslide, laboratory tests, liquefaction, shear strength, volcaniclastic soil 


\begin{abstract}
The island of Stromboli (Southern Italy) is a 4,000 $\mathrm{m}$ high volcanic edifice about $900 \mathrm{~m}$ above sea level. Most of the NW flank is formed by a wide scar (Sciara del Fuoco) filled by irregular alternations of volcaniclastic layers and thin lava flows. Between $29^{\text {th }}$ and $30^{\text {th }}$ December 2002, the Sciara del Fuoco slope was involved in a submarine and a subaerial retrogressive landslides,causing two tsunami waves with a maximum run-up of $10 \mathrm{~m}$. Mechanisms underlying the rapid submarine landslide and the preceding slower deformation of the subaerial and submarine slope were investigated through large-scale ring shear tests on the saturated and dry volcaniclastic material. The shear behaviour of the material under different drainage conditions was analyzed during tests conducted at DPRI (Kyoto University). Pore pressure generation, mobilized shear strength and grain crushing, within a range of displacements encompassing the different stages of evolution of the slope, were considered. Experimental results indicate that, even at higher displacements, shear strength of the dry material explains the virtual stability of the slope. Conversely, full or partial liquefaction can be invoked to explain the submarine failure and the subsequent long run-out (more than 1,000 m) of the failed materials.
\end{abstract}




\section{INTRODUCTION}

The Stromboli volcano, located on the homonymous island (North of Sicily, Italy), spreads products over its NW flank, called Sciara del Fuoco (hereafter indicated as the Sciara). Populated areas of the island (S. Vincenzo) mostly extend along the NE and E sides, very close to the coast (Fig. 1). Another village, Ginostra, lies on top of a small natural terrace behind the southern limit of the Sciara. From spring to early autumn, and other vacation periods, the population rises sharply due to the influx of tourists, particularly along the coastal areas. Hazard assessment directly or indirectly linked to the activity of the volcano and the slope instability is important in terms of population risk.

Until December 2002 sources of risk for inhabited areas at Stromboli were directly linked to volcanic phenomena, such as paroxysmal explosions and pyroclastic flows. However, between December $29^{\text {th }}$ and $30^{\text {th }} 2002$, some hours after the beginning of a major eruption, volcanic activity started an unexpected deformation and failure process of the Sciara slope. The thrust exerted by the intruded magma triggered a sequence of large-scale instability phenomena, culminating in a submarine and two subaerial landslides involving about 20 million $\mathrm{m}^{3}$ of slope materials (Tommasi et al. 2008). The landslides generated two series of tsunami waves which reached a maximum run-up of $10 \mathrm{~m}$ along the inhabited coasts of the Stromboli island (Tinti et al. 2005).

The Italian Civil Protection Department has supported research on the effects of the eruption, including an analysis of the instability mechanisms controlling the landslides. Consequently, a joint research between the National Research Council (Italy) and the Disaster Prevention Research Institute (DPRI), Kyoto University (Japan), was conducted. This is part of the UNITWIN Cooperation Programme "Landslide Risk Mitigation for Society and the Environment" promoted by UNESCO, Kyoto University and the International Consortium on Landslides (ICL). The research aimed to:

- characterize the mechanical behaviour of the volcaniclastic materials (i.e. the weakest component of the Sciara infilling deposit) in similar conditions to those that may have developed during the 
landslide processes;

- refine and support, using experimental evidence, the mechanisms of landslide initiation and propagation as suggested by Tommasi et al. (2005a) following post-failure observations and surveys.

A more comprehensive back-analysis of the failure and propagation phenomena would entail numerical modelling from the pre-failure stage to the early landslide propagation. This would also require developing a complex constitutive model capable of describing strength decay due to continuous grain crushing, liquefaction phenomena and propagation of the fluidised material.

On the other hand, experimental activity, as described in this study, can provide elements to support a conceptual model of the instability events.

The shear behaviour of the volcaniclastic material was investigated in dry and fully-saturated conditions, using a large-scale ring-shear apparatus developed at DPRI, Kyoto University. Using this apparatus it is possible to investigate the shear behaviour of coarse grained materials under various drainage conditions at different deformation levels. Both dry and fully-saturated specimens were tested to evaluate the behaviour of the material forming the subaerial and submarine slopes, respectively. Different drainage schemes were adopted for the fully-saturated tests to study the response of the submarine slope to different loading/strain mechanisms.

\section{GEOLOGICAL AND MORPHOLOGICAL CHARACTERS OF THE SCIARA DEL FUOCO SLOPE}

The island of Stromboli is the subaerial portion of a 4,000 $\mathrm{m}$ high volcanic edifice standing about $900 \mathrm{~m}$ above sea level. The persistent activity of the Stromboli volcano is concentrated at the summit of the NW flank. Its products are collected and driven down to the sea along the Sciara (Fig. 2). This is a scree slope representing the top of a more than $200-\mathrm{m}$ thick deposit. This fills the large scar left by the youngest lateral collapses that occurred 5.6 \pm 3.3 thousand years ago (Tibaldi 2001). The deposit mainly consists of irregular alternations of thick sequences of volcaniclastic layers and 
thin lava flows. Around the craters primary pyroclastic products are also found.

Volcaniclastic layers result from the continuous sliding of slope materials (both primary products and volcaniclastic materials ) and successive redistribution by small debris avalanches and grain flows. This incessant process produces sequences of irregular, mostly reverse-graded grain-supported layers (Fig. 3). Rounding, smoothness and sphericity progressively increase proceeding downslope, due to grain sliding and rolling (Kokelaar and Romagnoli 1995).

Volcaniclastic layers are the most abundant and weakest component of the Sciara deposit and extend continuously over extremely large areas (up to some $10^{5} \mathrm{~m}^{2}$ ) (Fig. 3).

Observations of the depositional process on the Sciara slope before and after the 2002 events indicate that lithology, grain size and structure of volcaniclastic materials, remain virtually unaltered over time. Therefore, continuous levels of loose granular materials, extending over large areas, probably also exist at depth and can represent preferable initiation paths for slip surfaces. Observations of the lateral scarp of the December 2002 subaerial landslides confirm that the structure of the deposit is recognizable right down to the bottom of the slide scar (i.e. $70 \mathrm{~m}$ below the original slope surface).

\section{DECEMBER 2002 TSUNAMIGENIC LANDSLIDES}

A detailed description of the instability events and their links with the volcanic activity is reported by Tommasi et al. (2005a). The eruption started in the early evening of December $28^{\text {th }}$. Initial observations carried out during helicopter surveys in the early morning of December $30^{\text {th }}$, confirmed by aerial photographs taken some days later, indicated that a relatively deep-seated landslide ( $\alpha$ in Fig. 4) had occurred in the preceding hours. Even though significant deformations had developed, the displaced mass had not slid into the sea. Deformations were concentrated in the upper half of the slope and propagated downslope, particularly in the southernmost part of the unstable sector of the Sciara, with a limited extension to the submarine slope.

In the early morning of December $30^{\text {th }}$, the slope relentlessly deformed and fragmented into 
several "blocks". The largest, which collapsed afterwards ( $\beta$ slide), extended from 450-500 m a.s.1, down to the shoreline (Fig. 4).

In the late morning, two series of tsunami waves originating from the SdF, hit the island's inhabited coastal areas (Tinti et al. 2005). The first tsunami wave was interpreted as being generated by a submarine slide, hereafter called $\Omega$ slide (Figs. 4 and 5). Bathymetric surveys show that the submarine slide involved a volume of about $6 \times 10^{6} \mathrm{~m}^{3,}$ leaving a sharp and relatively regular scar on the seafloor (Chiocci et al. 2008). The generation of the tsunami also indicates that the failure of the submarine deposit was sudden.

Once the foot of the subaerial slope had been undermined by the submarine slide, a large part of the subaerial slope, isolated by fractures, slid into the sea (slide $\beta$ ), producing a second tsunami wave. The related scar was apparent at the first helicopter recognition (Fig. 6). The run-out distance of both landslide masses was so long that no trace of landslide deposit was found as far down as 1000 meters below sea level.

An unconservative estimate of the maximum depth of the subaerial (slide $\alpha$ ) and submarine landslides (slide $\Omega$ ), obtained comparing pre- and post-bathymetric and photogrammetric surveys, indicated 75 and 45 meters, respectively (Tommasi et al. 2008).

\section{SAMPLING}

The material was sampled in April 2004 on outcrops of volcaniclastic sequences, corresponding to the lateral scarp of a small slide located at the foot of the slope (Figs. 1 and 3). In the sampling area the volcaniclastic sequences mainly consist of gravelly and sandy layers (box in Fig. 3), composed of angular to subangular clasts with high surface roughness and low sphericity.

This sampling site was chosen because it afforded a clear exposure of the volcaniclastic sequence. Location, too, was important, as this was relatively safe and close to the sole access point to the slope. Large sections of the Sciara slope are almost inaccessible due to continuous falls of products ejected by explosions and incessant rock falls and small debris avalanches. In such 
conditions in-situ, deep investigations (borehole sampling, penetration tests) cannot be carried out and geotechnical samples can only be taken from the surface layers.

Since the depositional process is repetitive, surface samples can be considered as being representative of the material existing at depth. State of stress at depth can be conveniently calculated as the lithostatic stress acting at the base of a strip within an infinite slope. Overconsolidation effects are in all likelihood not a factor to be considered. A certain equilibrium exists between erosional and depositional activity. Observations made during five years after the failures indicate that the slope has more or less re-established the existing morphology prior to the landslides (Baldi et al. 2008a, 2008b).

Collected samples were compared to bottom samples taken on the seafloor of the SE part of the submerged Sciara slope, untouched by the 2002 slide events. The purpose was to establish to what extent these are representative of the submarine materials. Rounding and sphericity of the grains of the submarine samples were found to be similar to those of the subaerial materials used for experimental investigations. A reliable grain size analysis of seafloor samples was not possible as submarine sampling (dredging, grab sampling) determined a loss of sandy sizes that cannot be evaluated. However, no material finer than sand was collected (Chiocci et al. 2008). These elements, together with the apparent depositional continuity between subaerial and submarine deposits, highlighted by bathymetric and photogrammetric surveys (Baldi et al. 2008, Tommasi et al. 2008), suggest that the subaerial material may also be used to analyse the shear behaviour of the submerged slope material.

\section{RESULTS FROM PREVIOUS TESTS}

\section{Lithological, physical and mechanical properties of the volcanic grains}

Physical and mechanical properties of grains were determined by Tommasi et al. (2005b and 2007). Scanning electron microscope showed grains that appeared to be formed by small lumps, ranging from a few tenths to a few millimetres in size, welded together so as to form a continuous 
frame (Figs. 7 and 8). Pores are extremely diffuse and generally do not exceed a few tenths of a millimetre in size, even though larger pores (up to 2-3 mm) are observed (Figs. 7 and 8). Most grains result from the disruption of the lava flow fronts during the cooling and advancing on the steep Sciara slope (autoclastic breccia); spatters from slides of the cinder cones are also present. Fragments of low-porosity aphanitic lava, coming from the core of the lava flows, are less frequent. The mean value of the density of the entire sample set, measured with a mercurium pycnometer, is $2.34 \mathrm{Mg} / \mathrm{m}^{3}$, with a standard deviation of $0.04 \mathrm{Mg} / \mathrm{m}^{3}$ (43 determinations). Solid matrix density, determined with a helium pycnometer on powders $\left(<0.074 \mathrm{~mm}\right.$, ) is on average $2.90 \mathrm{Mg} / \mathrm{m}^{3}$, yielding a mean value of the total porosity of the grains of $19.2 \%$, that is almost completely connected.

Grain strength, estimated through point load tests on larger clasts, largely depends on grain porosity. For a porosity of $20 \%$ the strength index $I_{\mathrm{S}, 50}$ is about 3.0 (Rotonda et al. 2008). The uniaxial compressive strength $U C S$, obtained from the correlation proposed by the ISRM (1985), is around $66 \mathrm{MPa}$. Bowden et al. (1998) point out that the multiplying factor $K\left(K=U C S / I_{\mathrm{S}, 50}\right)$ suggested by the ISRM, on the basis of tests on hard rocks, is not suitable for this type of rock. In fact, vesiculated basalts of similar porosity give a value of $K$ equal to 11 (Reid et al. 1980 in Bowden et al 1989). Rotonda et al. (2008) found an average value of about 6 for the Stromboli autoclastic breccia with a $20 \%$ porosity. This reduced UCS of the grains explains their high tendency to crush even at low contact stresses.

\section{Physical and mechanical properties of the volcaniclastic aggregate}

The grain size distribution of a typical layer of the volcaniclastic deposit is shown in Fig. 9. To ensure a convenient ratio between maximum grain and specimen sizes, tests were performed on the fractions passing the $8 \mathrm{~mm}$ sieve. The grain size distribution curve (Fig.9) was shifted parallel to the grain size axis, according to Fumagalli (1969), obtaining a sand with gravel, with a coefficient of uniformity of 9.6. 
Minimum and maximum void ratios, calculated from densities measured in the laboratory, using the ASTM standard procedure, are 0.41 and 0.72 , respectively. In situ void ratio was calculated from the in-situ density, determined on undisturbed samples taken by driving a large thin-walled sample into the top surface of the layer. Measurements on a volcaniclastic layer, with a particle size distribution similar to that of the material used in laboratory tests, yielded a void ratio of 0.83 .

The shear behaviour of the dry and fully-saturated material-was investigated using large-scale device direct shear (DS) and undrained $\mathrm{CU}-\mathrm{K}_{0}$ triaxial tests, respectively. DS tests showed an inverse correlation between volume changes and hardening behaviour. As the normal stress increases, a more marked softening behaviour is associated with a prevailing contractive behaviour. Conversely, a slightly positive hardening is observed at low normal stress. This result can be explained by the high crushability of the Stromboli clasts that, especially at high stresses, can cause a significant reduction in shear strength. Peak strength does not increase linearly with the applied normal stress, as is observed for other coarse-grained and rockfill-like materials (e.g., Marsal 1973; Indraratna et al. 1993). Linear regression of the data provided peak and post-peak friction angles of $42^{\circ}$ and $36^{\circ}$, respectively.

Strength data from triaxial tests provided a peak friction angle of $38^{\circ}$ and exhibited a lower curvature of the envelope within the same stress range. All specimens displayed only partial liquefaction, perhaps to be traced to the limited level of deformation and, hence, of grain crushing that can be attained in the triaxial apparatus.

\section{RING SHEAR TESTS}

\section{Aim of experimental activity}

Based on the reconstructed succession of the events that occurred in December 2002, a testing programme was defined to analyze the shear behaviour of the volcaniclastic material under the various conditions that arose during the evolution of the slope (i.e. at the initiation and propagation of the different landslides that occurred since the beginning of the eruption). To define the 
experimental activity the following succession of events was schematised:

1) Magma intruded into the slope from the volcano's feeding system and exerted a thrust on the dry volcaniclastic deposit, which was involved in a large first-time slide $(\alpha)$;

2) The southern part of the $\alpha$ slide ( $\beta$ slide) detached from the main slide body and started sliding at a higher displacement rate, experiencing large shear deformations along the slip surface;

3) The movement of the $\beta$ slide produced an undrained or partially drained loading of the fully-saturated submarine deposit culminating in a rapid submarine slide $(\Omega)$.

\section{$\underline{\text { Testing procedures }}$}

Tests were performed using the large-scale ring-shear apparatus DPRI-6, developed at the DPRI, Kyoto University (Sassa 1997). The methodology for shear testing with this new apparatus, and results obtained from simulations of shear processes occurring during different landslide phenomena (e.g. Otari debris flow disaster and earthquake-induced landslides in the upper slope of the Nikawa area), were reported by Sassa (1996) and Sassa et al. (1997, 2003 and 2004a).

The DPRI-6 device is characterised by an inner diameter of $250 \mathrm{~mm}$, an outer diameter of 350 $\mathrm{mm}$ and a maximum sample height of $150 \mathrm{~mm}$, hence suitable for testing coarse-grained volcaniclastic materials. Tests can be conducted in both drained and undrained conditions. This is thanks to a water-leakage tightness system, formed by O-rings on the upper loading platen, and bonding rubber edges on the two confining rings of the lower rotary pair (Sassa et al. 2004b). Pore pressure is measured by two transducers located $2 \mathrm{~mm}$ above the shear surface.

The sample was placed in the shear box using the dry pluviation method (see e.g. Ishihara 1985). To avoid segregation phenomena during infilling, the sample was initially subdivided into eight smaller parts, subsequently deposited in the apparatus in different layers without tamping. The void ratio expected at the depth where the shear surface is supposed to have developed was obtained by applying, during consolidation, the lithostatic normal and shear stresses acting at the base of a strip within an infinite slope. 
The first test was conducted in dry conditions. The material was subjected to an initial state of stress, reproducing in-situ stress conditions at the base of the $\alpha$ slide body. The slip surface was estimated to be located at an average depth of $66 \mathrm{~m}$ with an average dip of $33^{\circ}$ (Fig. 5). By assuming a dry unit weight $\gamma_{\mathrm{d}}=13 \mathrm{kN} / \mathrm{m}^{3}$ (equal to that obtained from in-situ measurements), the sample was anisotropically consolidated at a normal stress of $600 \mathrm{kPa}$ and at a shear stress of 390 $\mathrm{kPa}$. At the end of the consolidation phase, the dry unit weight reached a value of $17.3 \mathrm{kN} / \mathrm{m}^{3}$.

Assuming that the dip of the shear surface of the landslides does not vary significantly throughout the slope, the shearing stage was conducted by increasing the shear torque with a loading rate of $204 \mathrm{~Pa} / \mathrm{s}\left(0.12 \mathrm{kgf} / \mathrm{cm}^{2} / \mathrm{min}\right)$.

The second set of tests was conducted in fully-saturated conditions. Full saturation was obtained by supplying the sample with a $\mathrm{CO}_{2}$ flux followed by a de-aired water flux for a sufficient length of time (generally more than 12 hours) to obtain a $B_{\mathrm{D}}$ value (Skempton's pore pressure parameter $B$ in direct shear condition, Sassa 1988) above 0.95 .

Since the loading rate and the related drainage conditions of the $\Omega$ slide are uncertain, two different types of torque-controlled tests were performed: undrained shear tests and shear tests with open drainage from the sample top through the upper loading platen. During the latter procedure drainage is not prevented, but excess pore pressure can be generated depending on material behaviour and loading rate (these conditions are referred to as naturally drained conditions (Sassa et al. 2004a)).

In both cases, samples were first consolidated at an anisotropic state of stress corresponding to that along the slip surface of the slide $\Omega$, characterized by an average depth and dip of $37 \mathrm{~m}$ and $28^{\circ}$, respectively. Therefore, a normal stress of $230 \mathrm{kPa}$ and a shear stress of $122 \mathrm{kPa}$ were applied. At the end of the consolidation phase, the dry unit weight ranged between 16.6 and $17.2 \mathrm{kN} / \mathrm{m}^{3}$. The shearing stage was carried out by applying a shear torque with a loading rate of $55 \mathrm{~Pa} / \mathrm{s}$. 


\section{Shear behaviour of the subaerial material}

Time-histories of normal stress and shear resistance are plotted in Fig. 10a and 10b. Shear resistance increased linearly, according to the linear increase of the applied torque, up to a peak value corresponding to an instantaneous friction angle of $40^{\circ}$ (with two short hold-ups). After peak, the shear strength decreased to a value corresponding to an instantaneous friction angle of $34^{\circ}$, which remained constant for the rest of the test. Due to the torque-controlled procedure, the drop of shear resistance after peak was accompanied by a sudden increase of the shear displacement rate.

These results are comparable to those obtained by Tommasi et al. (2007) through DS tests. The higher instantaneous peak friction angle $\left(42^{\circ}\right)$ is probably due to the much lower displacement rate.

The peak friction angle is higher than the average dip of both the subaerial slope $\left(35^{\circ}-36^{\circ}\right)$ and the $\alpha$ slip surface $\left(33^{\circ}\right)$. The latter is also lower than the residual friction angle of the volcaniclastic material. This is indirect evidence that without a magmatic intrusion the subaerial slope would not likely have failed with the slope geometry existing in December 2002.

\section{Shear behaviour of the submerged material}

\section{Undrained test}

Figures 11 reports time-histories of total normal stress, shear resistance, pore pressure and shear displacement. Data are shown both for the whole test (Fig. 11a) and in detail for the near-failure stage (Fig. 11b). Effective and total stress paths are plotted in Figure 12.

During the first stage of the test, excess pore pressure generated as shear stress increased, producing a decrease in the effective normal stress (Fig. 12). This behaviour inverted when pore pressure reached about $25 \mathrm{kPa}$; from this point material dilation induced a progressive decrease in pore pressure down to negative values, producing a progressive increase in the effective normal stresses (Fig. 11a). When pore pressure reached about $-37 \mathrm{kPa}$, the volcaniclastic material experienced liquefaction: pore pressure rose to values higher than $200 \mathrm{kPa}$, shear resistance abruptly 
decreased to a few kilopascals and, correspondingly, the shear displacement rate increased significantly (Fig. 11b).

The apparent friction angle at the final stage (given by the arctangent of the ratio between the mobilised shear resistance and the total normal stress) is about $3^{\circ}$, showing a high mobility of the material under undrained shearing in the liquefied state.

The angularity and surface roughness, typical of volcanic grains, caused the dilatant behaviour which induced negative excess pore pressures down to $-37 \mathrm{kPa}$. Dilatant behaviour was also recorded by other authors (e.g., Castro 1969) in the initial stage of triaxial tests on medium-dense sands, which display a strain-softening behaviour after dilation takes place, without being affected by liquefaction. Liquefaction of medium-dense to dense sands has been previously observed in ring-shear tests performed in undrained conditions at DPRI by Sassa (1996) and Wang and Sassa (2002). They demonstrated that, irrespective of the initial void ratio of the soil, liquefaction can be triggered if the following two conditions are verified:

1) the shear stress has to be great enough to initiate failure of the soil;

2) soil grains have to crush during shearing under the applied normal stress.

Since grain crushing causes volume reduction, excess pore pressure is generated. Furthermore, production of fines within the shear zone decreases permeability and, in turn, the rate of excess pore pressure dissipation.

Grains from the Stromboli volcaniclastic deposit were highly crushable under the investigated test conditions. Crushing, induced by shearing, is apparent both at a visual analysis of the shear zone (Fig. 13) and from the comparison of grain size distributions, determined before and after the test (Fig. 9).

\section{Shear test with open drainage}

A further test was conducted allowing drainage at the specimen top. Time-histories of total normal stress, shear resistance and shear displacement are plotted in Figure 14. 
Initially the shear resistance increased gradually up to a maximum value, corresponding to a peak friction angle of about $44^{\circ}$. The linear increase of shear indicates that shearing is likely to occur under drained conditions. After peak, the shear resistance temporarily dropped to a value corresponding to an apparent instantaneous friction angle of $18^{\circ}$ and thereafter increased up to a stable value, yielding a friction angle at large displacements of roughly $34^{\circ}$.

The drop in shear resistance is probably a consequence of the local development of excess pore pressures within the shear zone, which can build up due to the high crushability of the Stromboli volcaniclastic material. Since the rate of grain crushing and, in turn, the rate of pore pressure generation, possibly decreased as shear displacement proceeded, excess pore pressure soon decayed and the shear resistance was recovered up to a value corresponding to a friction angle of about $34^{\circ}$ (Fig. 14).

The peak friction angle measured in this test $\left(44^{\circ}\right)$ was higher than that determined in dry conditions $\left(40^{\circ}\right)$. This difference is due to the fact that the strength envelope of the Stromboli volcaniclastic aggregate is non-linear (Tommasi et al. 2007); indeed a higher normal stress was applied in the test on the dry material. Non linearity of the strength envelope is typical of coarse grained materials (Marsal 1973; Indraratna et al. 1993) and particularly of those with crushable grains (Miura et al., 2003).

The same value of the angle of shear strength measured at large displacements in RS tests on both dry and saturated material seems to indicate that the strength of the volcaniclastic aggregate at large displacements is somewhat independent of the initial conditions.

\section{DISCUSSION AND CONCLUSIONS}

The dry, normally consolidated, Stromboli volcaniclastic material displays a high peak friction angle and high dilatancy in the initial shearing stage, due to the angularity and surface roughness of grains. This supports the hypothesis that an additional thrust by magma, intruded in the upper part of the slope, was necessary to spark off the initial deep-seated instability that was instrumental in 
the further evolution of the slope. Even though strength drops after peak and successively decreases as displacements proceed, the angle of shear resistance remains relatively high at large displacements. This behaviour accounts for the tendency of the slope to reach equilibrium after failure episodes that are not followed by a complete disruption of the slide mass.

Results of the undrained test indicate that, if excess pore pressure generated in the submerged slope during shearing could not dissipate, liquefaction can be invoked to explain the submarine failure. Such a sudden drop in strength would also imply a sudden slope failure and the consequent generation of relatively high tsunami waves.

Pore pressure rise occurs after the material has experienced significant shear displacements. as well as a sizeable reduction in grain size due to crushing. This would appear to be a prerequisite to causing liquefaction failure. In fact $101 \mathrm{~mm}$ in diameter specimens of the same material, prepared

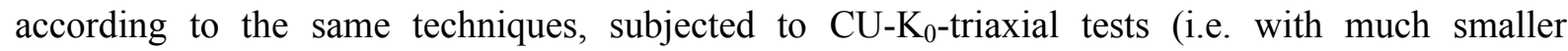
deformations), only exhibited a partial liquefaction followed by a prompt strength recovery (Tommasi et al. 2007). Regarding the evolution of the Sciara slope on December $30^{\text {th }} 2002$, this behaviour would explain why failure was preceded by a relatively long phase of continuous deformations.

Furthermore, the sharp reduction of the apparent friction angle of the saturated material in undrained conditions by a few degrees, helps explain the subsequent long run-out of the marine landslide (much greater than $1000 \mathrm{~m}$ ).

The open drainage test performed, however, provides experimental evidence that a significant drop in shear resistance, which would have been sufficient to lead the slope to failure, can be expected even when excess pore pressure dissipation is not completely prevented. In this test, too, the increase in pore pressure occurs after the material has experienced relatively large displacements (almost three times greater than those reached in the undrained text).

Even though there is no indication regarding the displacement/loading rate during the stage preceding the submarine slide, the two experimental conditions could be related to different 
deformation processes occurring in the submarine slope immediately before failure.

Failure occurred when shear stress reached a threshold value at which grains experienced a significant crushing and local excess pore pressure might be generated. This mechanism seems to correspond to the conditions existing in the open drainage test and would require a greater reduction in grain size and, hence, permeability.

Alternatively, the shear displacement rate at the base of the sliding mass sharply increased during the fragmentation of the subaerial slope (Tommasi et al. 2005a) or resulted from local sudden failures of more resistant parts of the slope. This second mechanism could have locally induced a much more rapid increase in excess pore pressures, compared to the time required for their dissipation and, therefore, could be better represented by conditions that occur in the fully undrained tests.

\section{Acknowledgements}

National Research Council funding, part of the "Short-term mobility" research programme, to visit the Research Centre on Landslides of the Disaster Prevention Research Institute, Kyoto University was greatly appreciated. Grateful thanks to K. Kondo for apparatus maintenance, Tatiana Rotonda for the physical characterization of the material and Roberto D'Inverno and Filippo Cignitti for preparing samples for ring-shear tests.

\section{References}

Baldi P, Coltelli M, Fabris M, Marsella M, Tommasi P (2008a) High precision photogrammetry for monitoring the evolution of the NW flank of Stromboli volcano during and after the 2002-2003 eruption, Bullettin of Volcanology, 70: 703-715

Baldi P, Bosman A, Chiocci FL, Marsella M, Romagnoli C, Sonnessa A (2008b) Integrated subaerial-submarine evolution of the Sciara del Fuoco after the 2002 landslide, In "Learning from Stromboli" (AGU Book), Calvari et al. Eds, AGU, Washington D.C., in press 
Boldini D, Wang FW, Sassa K, Tommasi P (2005) Mechanism of landslide causing the December 2002 tsunami at Stromboli volcano (Italy). Landslide: Risk Analysis and Sustainable Disaster Management, 173-180

Castro G (1969) Liquefaction of sands. Ph.D. thesis, Harvard University, Cambridge, Massachusetts

Chiocci FL, Romagnoli C, Tommasi P, Bosman A (2008) The Stromboli 2002 tsunamigenic submarine slide: characteristics and possible failure mechanisms, Journal of Geophysical Research - Solid Earth, doi:10.1029/2007JB005172

Fumagalli E (1969) Tests on cohesionless materials for rockfill dams. Journal of Soil Mechanics and Foundation Engineering Division (ASCE), 95 (SMI): 313-330

Indraratna B, Wijewardena LSS, Balasubramaniam AS (1993) Large-scale triaxial testing of greywacke rockfill. Géotechnique, 43(1): 37-51

Ishihara K (1985) Stability of Natural Deposits During Earthquakes. Proceeding of the XI ICSMFE, Theme Lecture, 2:321-376.

ISRM (1985) Suggested Method for determining point load strength. International Journal of Rock Mechanics, Mining Sciences and Geomechanical Abstracts, 22: 51-60

Kokelaar P, Romagnoli C (1995) Sector collapse, sedimentation and clast population evolution at an active island-arc volcano: Stromboli, Italy. Bulletin of Volcanology, 57: 240-262

Marsal RJ (1973) Mechanical properties of rockfill. Embankment-Dam Engineering. Casagrande volume, $109-200$

Migliazza R, Segalini A, Tommasi P (2003) Experimental studies on the mechanical behavior of pyroclastic material. Proceedings of 12th Panamerican on Soil Mechanical and Geotechnical Engineering and 39th U.S. Rock Mechanics Symposium Soil-Rock America 2003, 2: 501-506

Miura S, Yagi K, Asonuma T (2003) Deformation-strength evaluation of crushable volcanic soils by laboratory and in-situ testing. Soils and Foundations, 43(4): 47-57

Rotonda T, Tommasi P, Boldini D (2008) Geomechanical characterization of the volcaniclastic material involved in the 2002 landslides at Stromboli volcano (Italy). Journal of Geotechnical 
and Geoenvironmental Engineering, submitted.

Sassa K (1988) Geotechnical model for the motion of landslides. Proceedings of the $5^{\text {th }}$ International Symposium on Landslides, Special Lecture, 1: 37-55

Sassa K (1996) Prediction of earthquake induced landslides. Proceedings of 7th International Symposium on Landslides, 1: 115-132

Sassa K (1997) A new intelligent type dynamic loading ring-shear apparatus. Landslide News, $10: 1-33$

Sassa K, Fukuoka H, Wang FW (1997) Mechanism and risk assessment of landslide-triggered-debris flows: lesson from the 1996.12.6 Otari debris flow disaster, Nagano, Japan. Proceedings of the International Workshop on Landslide Risk Assessment, 347-356

Sassa K, Wang G, Fukuoka H (2003) Performing undrained shear tests on saturated sands in a new intelligent type of ring-shear apparatus. Geotechnical Testing Journal, 26 (3): 257-265

Sassa K, Wang G, Fukuoka H, Wang FW, Ochiai T, Sugiyama M, Sekiguchi T (2004a) Landslide risk evaluation and hazard mapping for rapid and long-travel landslides in urban development area. Landslides, 1 (3): 221-235

Sassa K, Fukuoka H, Wang G, Ishikawa H (2004b) Undrained dynamic-loading ring-shear apparatus and its application to landslide dynamics. Landslides, 1(1): 9-17

Smith HJ (1997) The point load test for weak rock in dredging applications. International Journal of Rock Mechanics \& Mining Sciences, 34:3-4

Tibaldi A (2001) Multiple sector collapses at Stromboli volcano, Italy: how they work. Bulletin of Volcanology, 63:112-125

Tinti S, Manucci A, Pagnoni G, Armigliato A, Zaniboni F (2005) The 30 December 2002 landslide-induced tsunami in Stromboli: sequence of the events reconstructed from the eyewitness accounts. Natural Hazards and Earth System Sciences, 5:763-775

Tommasi P, Baldi P, Chiocci FL, Coltelli M, Marsella M, Pompilio M, Romagnoli C (2005a) The landslide sequence induced by the 2002 eruption at Stromboli volcano. Landslide: Risk Analysis 
1

and Sustainable Disaster Management, 251-258

Tommasi P, Boldini D, Rotonda T (2005b) Preliminary characterization of the volcaniclastic material involved in the 2002 landslides at Stromboli. Proceedings of the International Conference on Problematic Soils GEOPROB, 3:1093-1101.

Tommasi P, Boldini D, Cignitti F, Graziani A, Lombardi A, Rotonda T (2007) Geomechanical analysis of the instability phenomena at Stromboli. Volcano. Proceedings of 1st Canadian-U.S. Rock Mechanics Symposium, Vancouver, 933-941

Tommasi P, Baldi P, Chiocci FL, Coltelli M, Marsella M, Romagnoli C (2008) Slope failures induced by the December 2002 eruption at Stromboli volcano. In "Learning from Stromboli" (AGU Book), Calvari et al. Eds. AGU, Washington D.C., in press

Wang G, Sassa K (2002) Post-failure mobility of saturated sands in undrained load-controlled ring-shear tests. Canadian Geotechnical Journal, 39:821-837. 


\section{Figure captions}

Fig. 1: Map of Stromboli island.

Fig. 2: View of the Sciara del Fuoco from the sea before the 2002 landslides (the outer area corresponds to the visible limit of the alfa movement whilst the inner area correspond to the limit of the beta slide).

Fig. 3: View of the Sciara foot after the 2002 landslides and detail of the volcaniclastic deposit (in the foreground a major lava flow of the 1985 eruption).

Fig. 4: Limits of the major instability phenomena that occurred on December $30^{\text {th }} 2002$ (from Tommasi et al. 2005b).

Fig. 5: Profile of the Sciara del Fuoco slope. Slip surfaces, reconstructed by comparison of preand post-slide morphology, are shown.

Fig. 6: View of the Sciara del Fuoco from the sea in 2004, two years after the 2002 landslides.

Fig. 7: Macrophotograph of grains forming the volcaniclastic aggregate.

Fig. 8: SEM microphotographs of black (on the left) and reddish (on the right) scoriae.

Fig. 9: Particle size distribution curves of in-situ material and tested material before and after the tests.

Fig. 10: Time histories of total normal stress, shear resistance and shear displacements recorded during a dry ring-shear test: a) data of the whole test; b) detail of the near-failure stage.

Fig. 11: Time-histories of total normal stress, shear resistance, pore pressure and shear displacement recorded during the undrained ring-shear test: a) data of the whole test; b) detail of the near-failure stage.

Fig. 12: Effective and total stress paths of the undrained ring-shear test.

Fig. 13: View of the shear zone after the test. The occurrence of grain crushing is visible.

Fig. 14: Time-histories of total normal stress, shear resistance and shear displacement recorded during the ring-shear test with open drainage. 


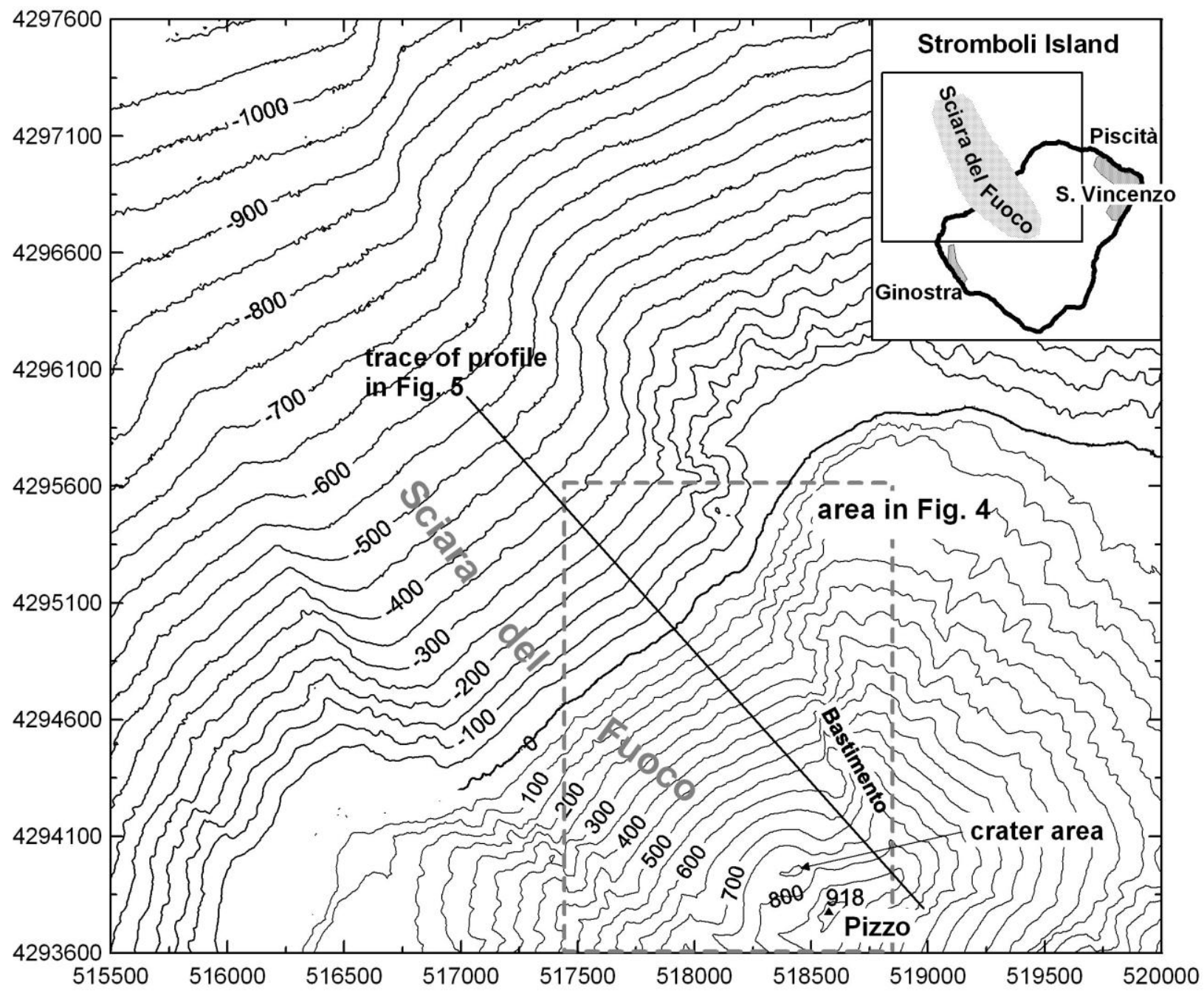

Figure 1 


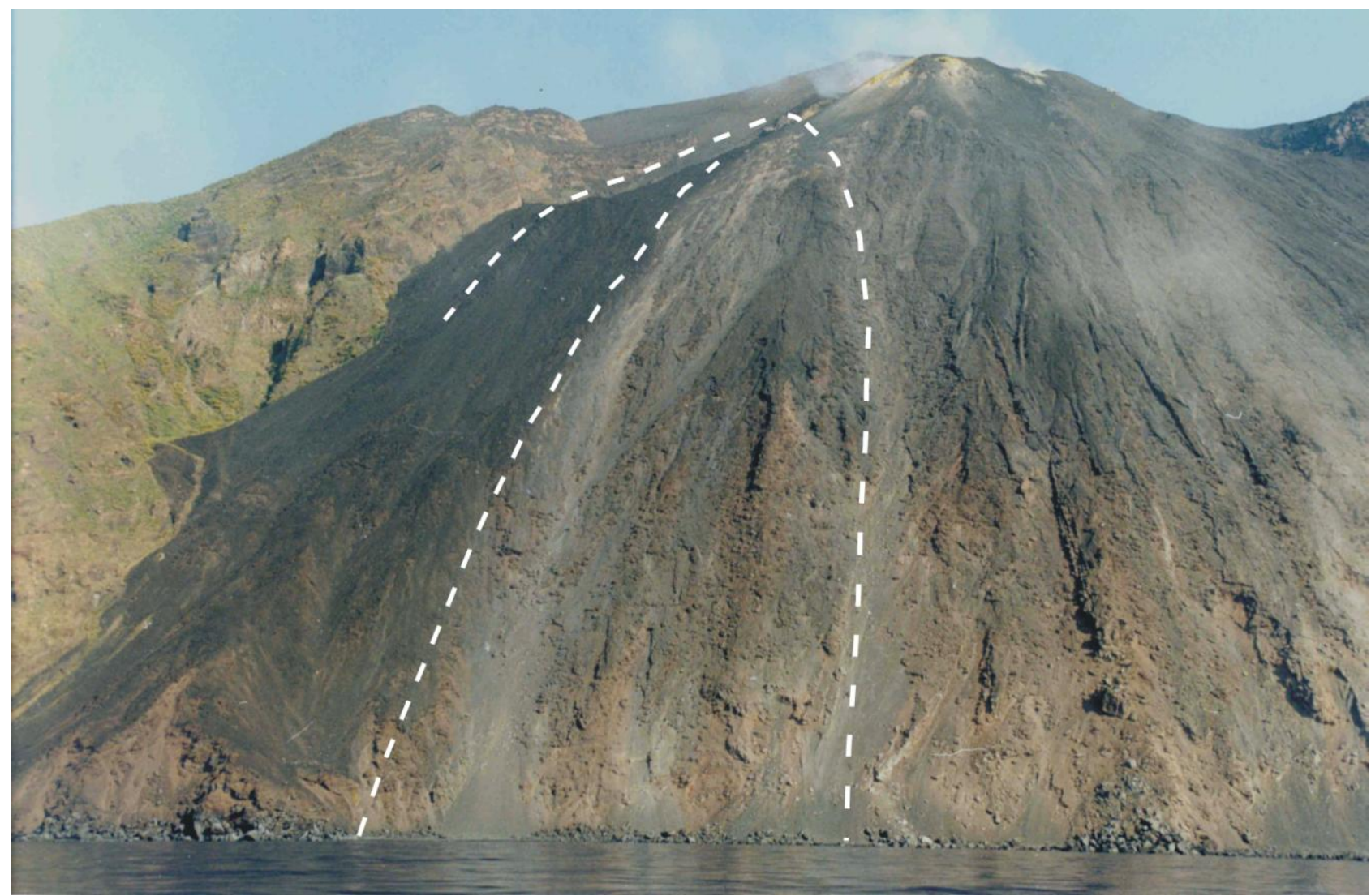

Figure 2

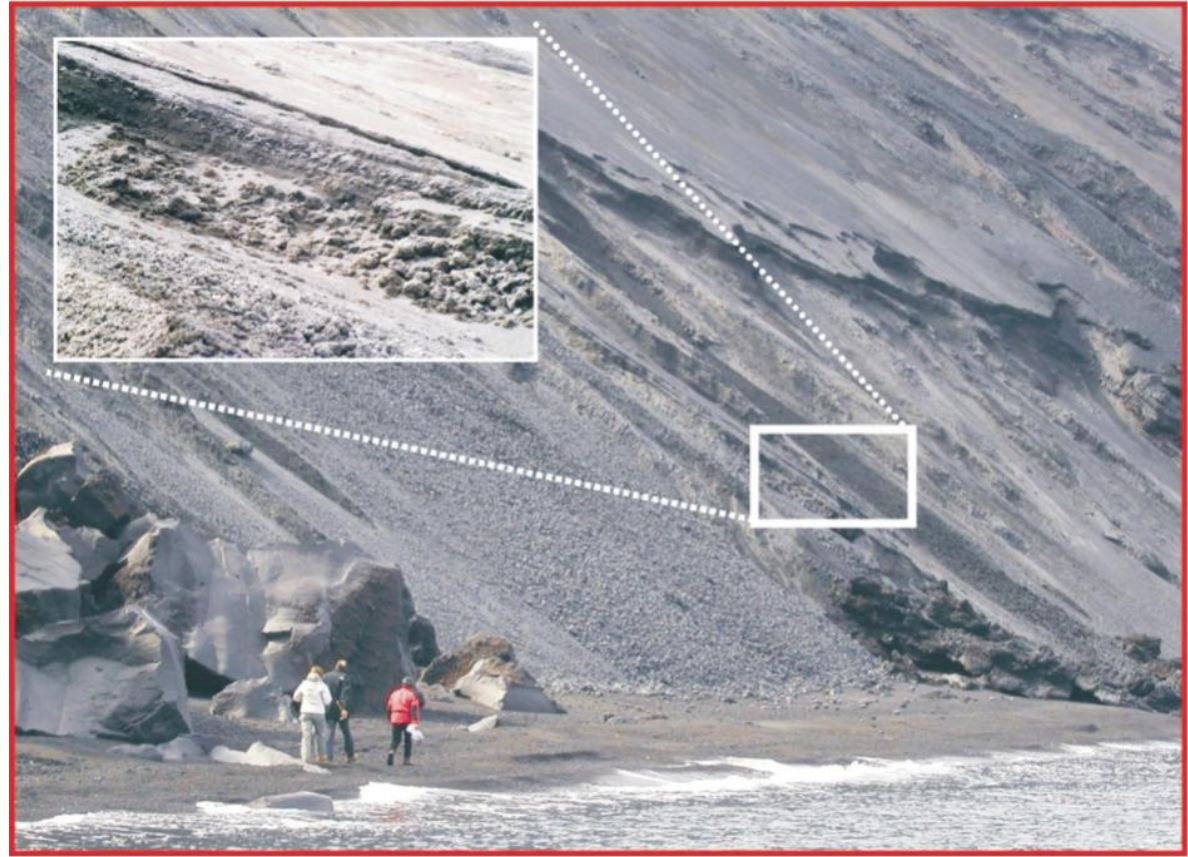

Figure 3 


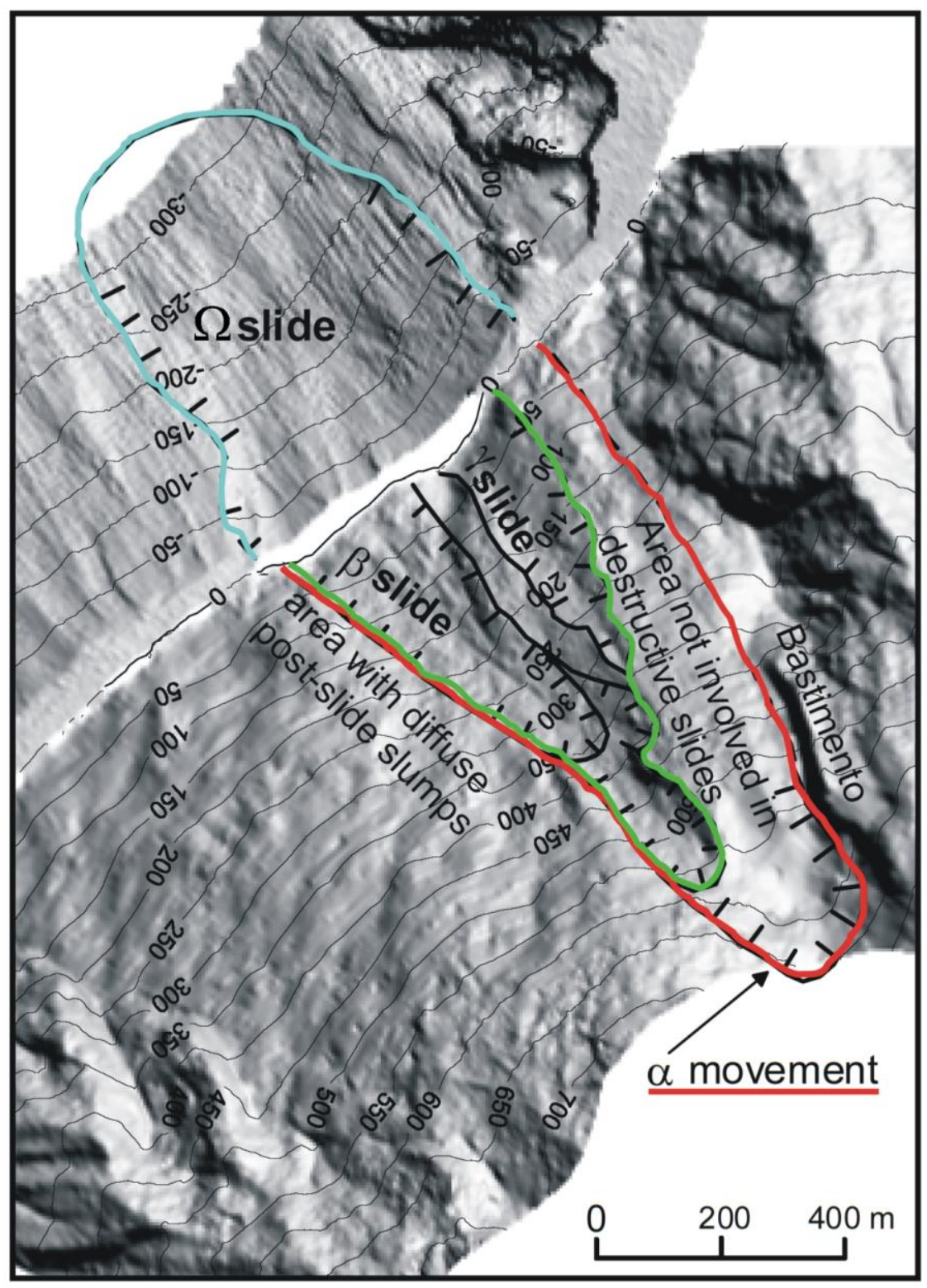

Figure 4 


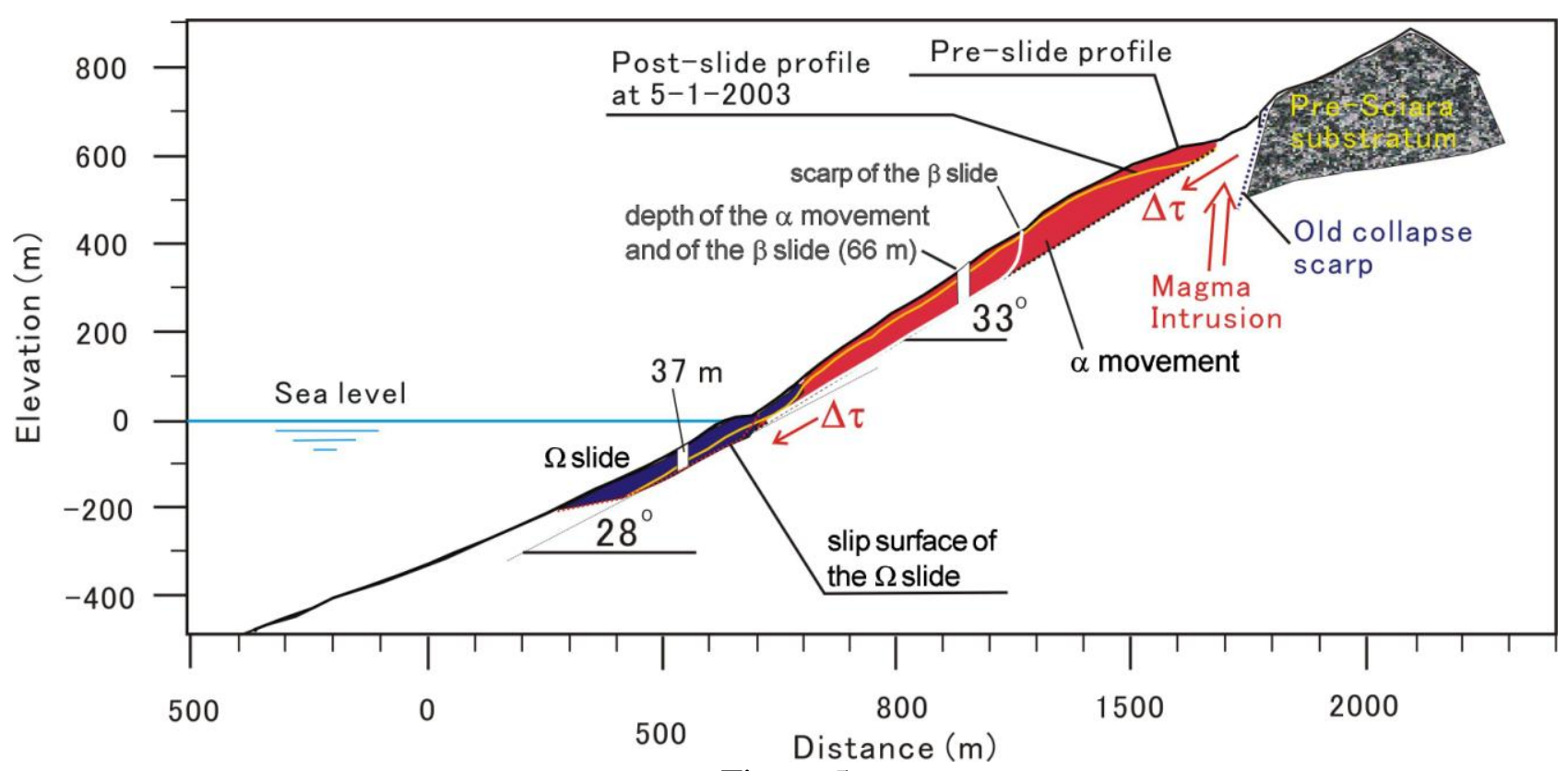

Figure 5

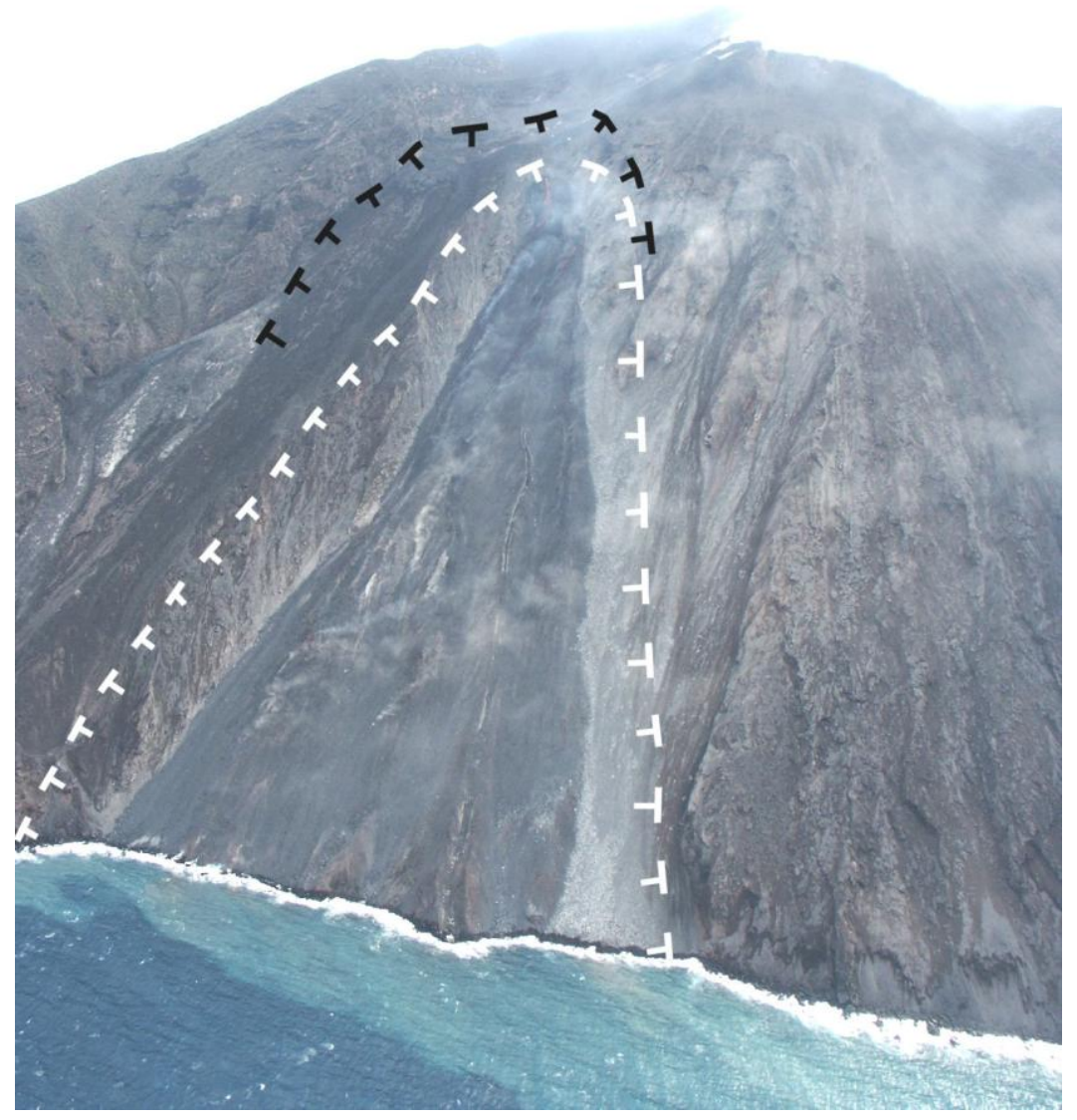

Figure 6 


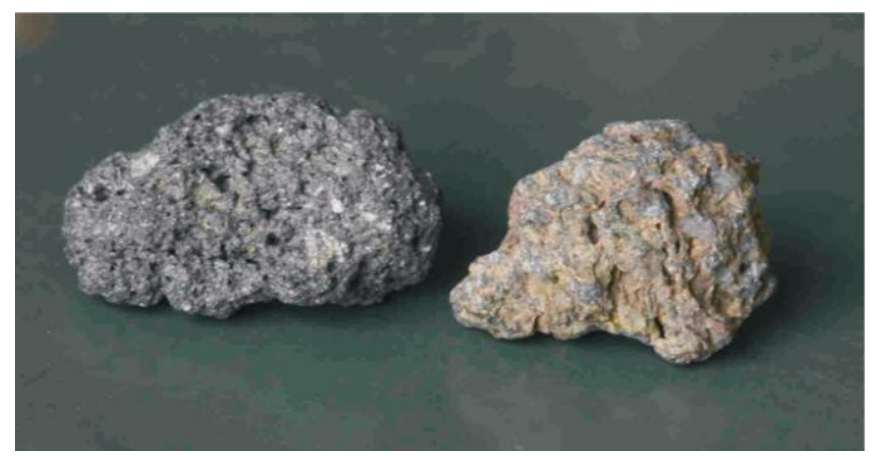

Figure 7
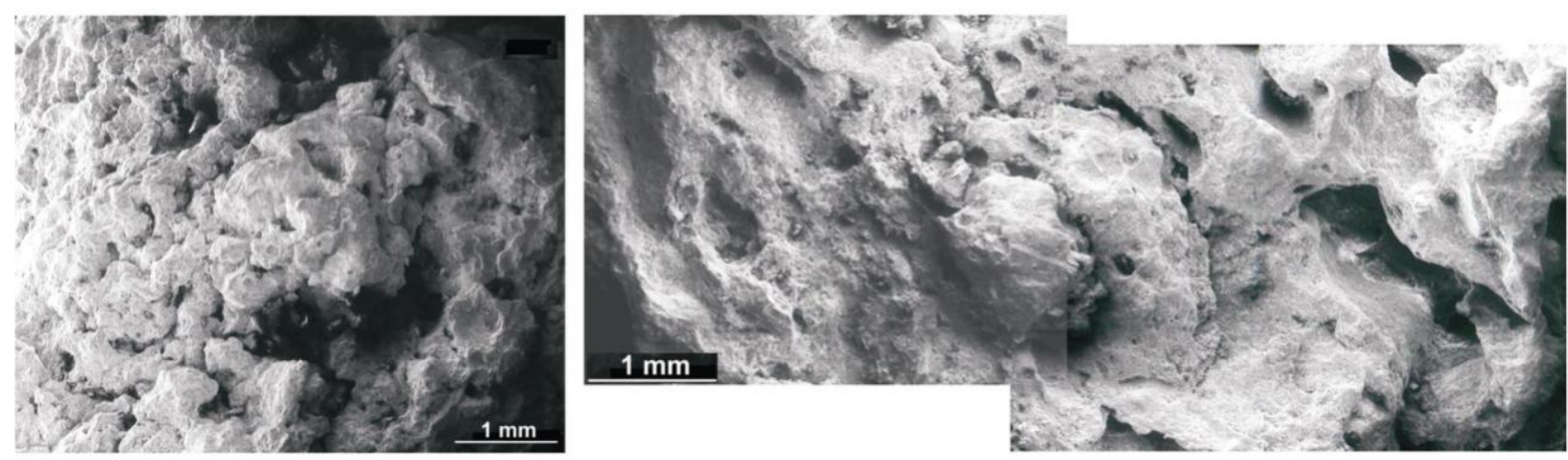

Figure 8

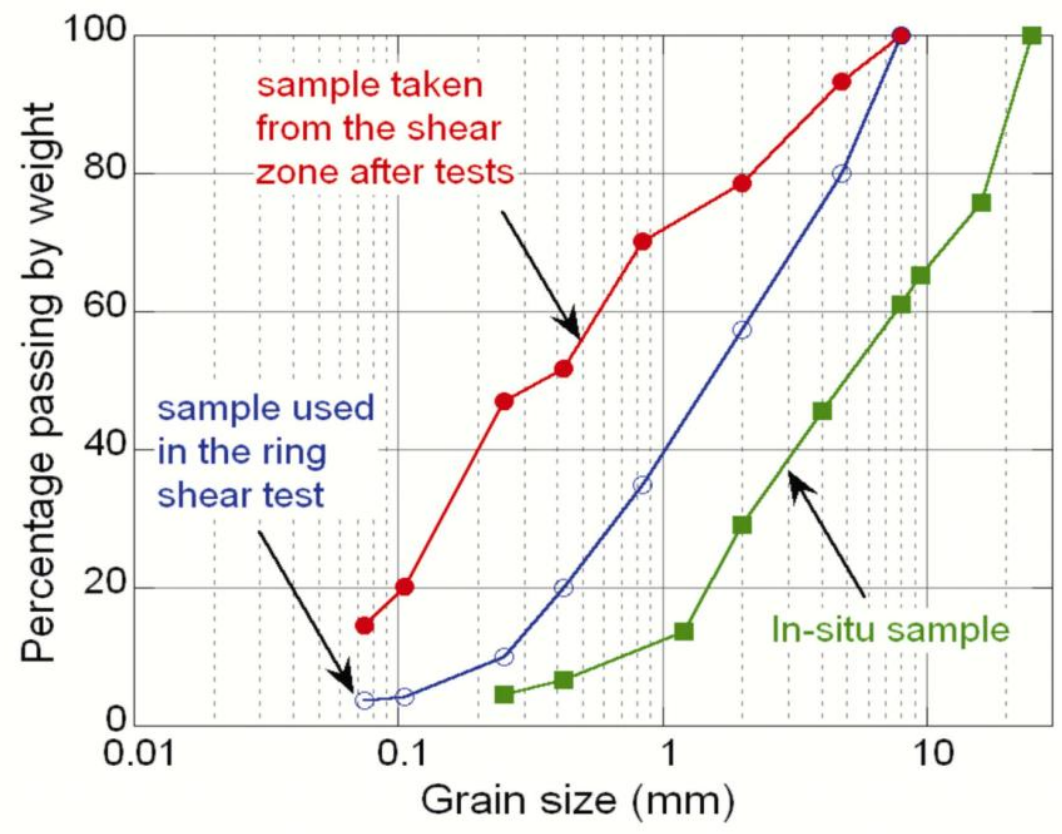

Figure 9 

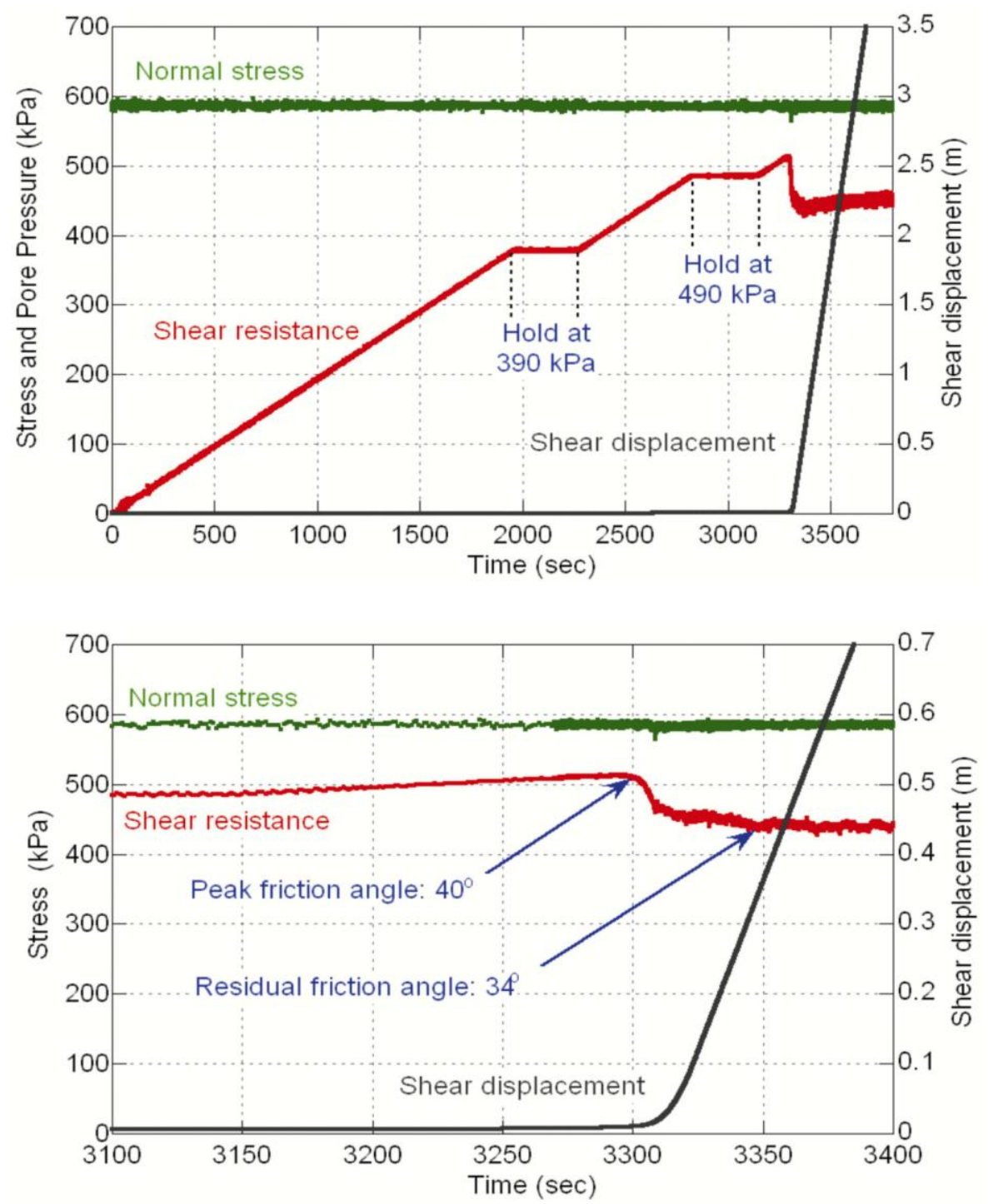

Figures 10a and 10b 

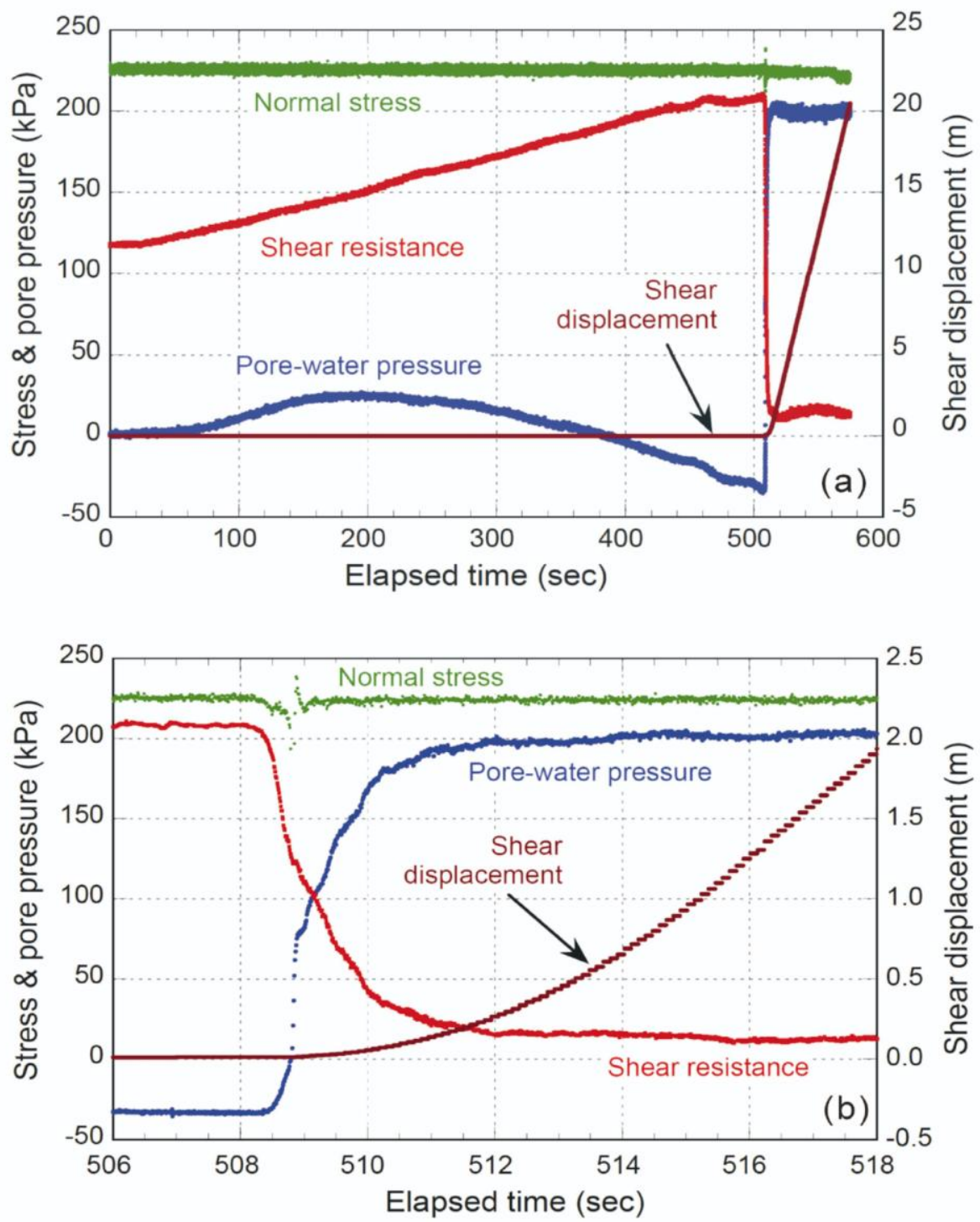

Figures 11a and 11b 


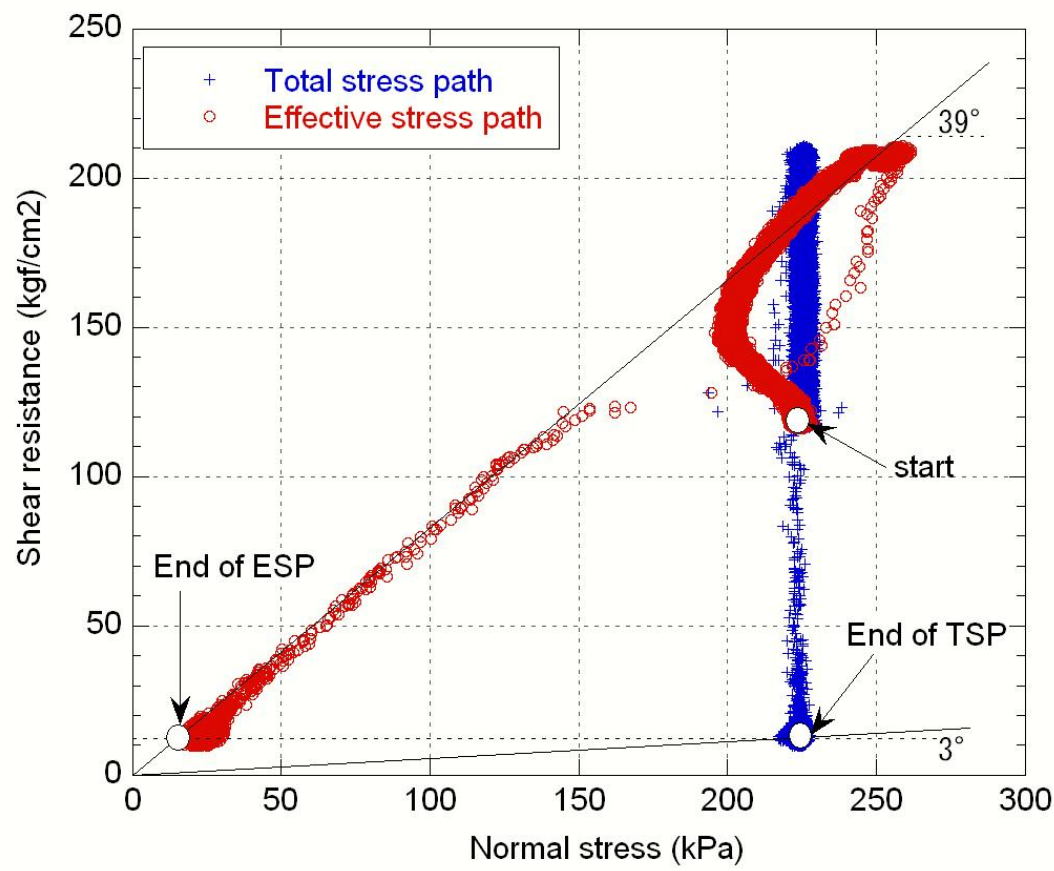

Figure 12

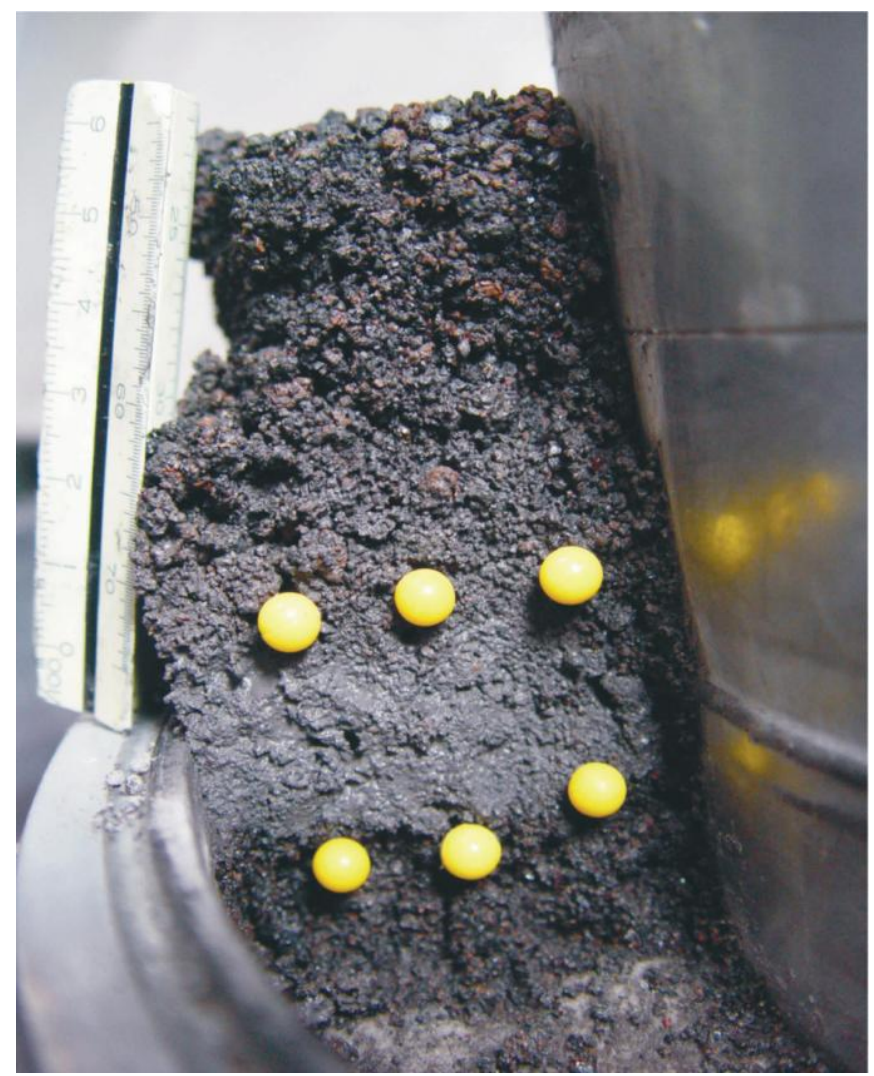

Figure 13 


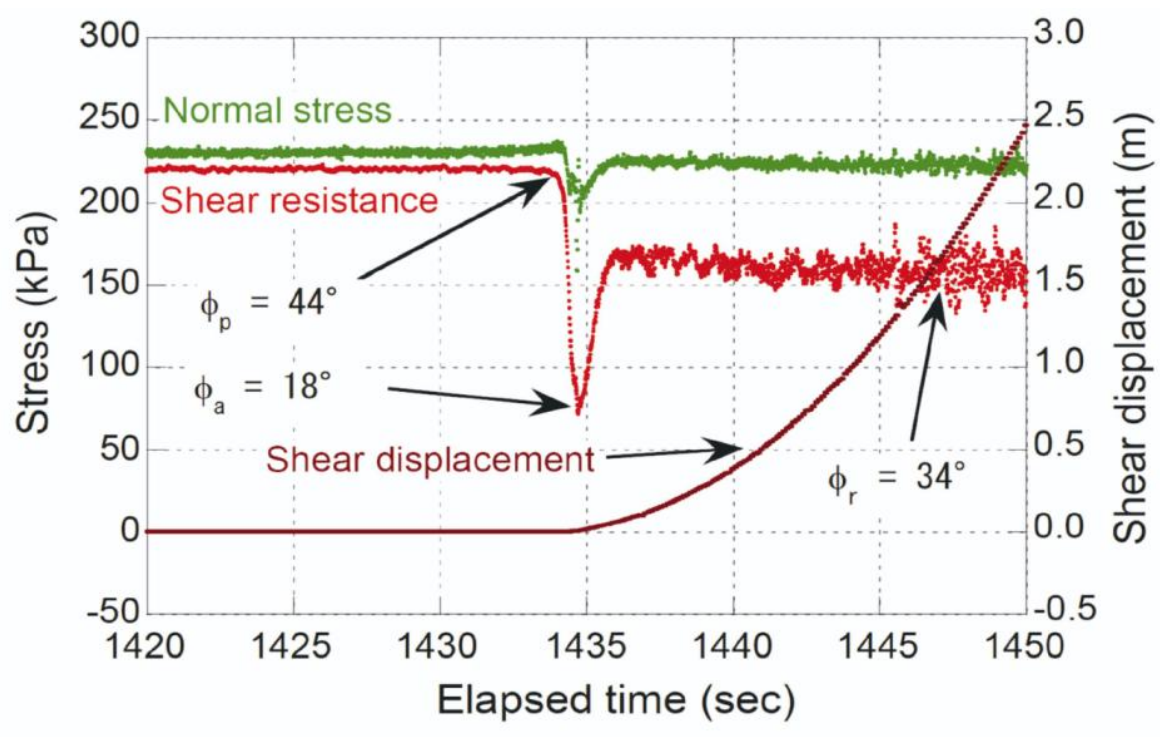

Figure 14 